\title{
COOPERATIVE LEARNING MAKE A MATCH DALAM PEMBELAJARAN READING COMPREHENSION DI KELAS IV SEKOLAH DASAR
}

\author{
Sigit Vebrianto Susilo \\ Dosen PGSD Fapendasmen-UNMA
}

\begin{abstract}
ABSTRAK
Penelitian Tindakan Kelas ini dilatarbelakangi oleh adanya permasalahan dalam kegiatan pembelajaran bahasa Inggris di SD. Pembelajaran bahasa Inggris di SD cenderung lebih fokus terhadap penggunaan buku pegangan siswa, sehingga ketika siswa mendapat instruksi dalam bahasa Inggris, siswa kurang mampu memahami, merespon, dan melakukan tindakan dengan baik. Penelitian ini dilakukan untuk mengetahui bagaimana proses pembelajaran reading comprehension dengan menggunakan cooperative learning make a match. Selain itu, penelitian ini juga dilakukan untuk mengetahui bagaimana hasil belajar siswa dalam pembelajaran reading comprehension setelah menggunakan cooperative learning make a match. Penelitian dilakukan di kelas IV SDN Sindangkasih II Kecamatan Majalengka Kabupaten Majalengka dengan jumlah siswa 24 orang. Penelitian dilakukan dalam tiga siklus penelitian. Masing-masing siklus terdiri atas tiga tindakan dengan tema pembelajaran yang berbeda, tetapi menggunakan model yang sama yaitu cooperative learning make a match. Adapun instrumen yang digunakan berupa RPP, lembar kerja siswa, lembar observasi, wawancara, catatan lapangan, lembar evaluasi, dan dokumentasi. Sedangkan teknik pengumpul data yang dilakukan adalah observasi, wawancara, catatan lapangan, tes, dan dokumentasi. Analisis data dilakukan dengan pendekatan kualitatif dan kuantitatif. Data kualitatif diolah secara deskriptif, sedangkan data kuantitatif diolah dengan cara mencari persentase dan rerata. Aspek yang dinilai dalam reading comprehension adalah ketepatan siswa dalam menjawab soal-soal dalam lembar kerja siswa.
\end{abstract}

Kata Kunci: cooperative learning make a match, reading comprehension

\section{Pendahuluan}

Pentingnya pendidikan telah diatur dalam Undang-undang Nomor 20 Tahun 2003 tentang Sistem Pendidikan Nasional (Sisdiknas) pasal (1) dan (2), dinyatakan bahwa:

(1) Pendidikan adalah usaha sadar dan terencana untuk mewujudkan suasana belajar dalam proses pembelajaran agar peserta didik secara aktif mengembangkan potensi dirinya untuk memiliki kekuatan spiritual, keagamaan, pengendalian dirinya, masyarakat, bangsa dan negara.

(2) Pendidikan nasional adalah pendidikan yang berdasarkan
Pancasila dan undang-undang tahun 1945 yang berakar pada nilai-nilai agama, kebudayaan nasional Indonesia dan tanggap terhadap tuntutan perubahan zaman. (Depdiknas, 2010)

Bertemali dengan peta konsep pada hal di atas, pendidikan di arahkan untuk meningkatkan kompetensi belajar siswa. Salah satu kompetensi yang penting adalah kompetensi bahasa. Kompetensi ini sudah dipelajari sejak anak usia dini.

Bahasa adalah kebutuhan yang diperlukan oleh manusia untuk berinteraksi dan berkomunikasi dengan orang lain. 
Abidin (2010) mengatakan bahwa bahasa sebagai alat komunikasi mengandung pemahaman yang cukup dalam karena proses komunikasi dapat terjadi apabila penerima pesan mampu memahami apa yang dimaksud oleh pengirim pesan. Dengan definisi diatas, penulis mempunyai pandangan bahwa bahasa memang perlu dipelajari sebagai alat komunikasi dan interaksi antara satu individu dengan individu lainnya. Hal ini disebabkan peran bahasa sebagai sarana untuk menyampaikan informasi ataupun berkomunikasi baik secara langsung ataupun tidak langsung. Secara langsung misalnya dengan bertatap muka dan secara tidak langsung misalnya dengan surat.

Crystal (2003:66-68), mengatakan bahwa jumlah penutur bahasa Inggris yang fasih atau kompeten sekitar seperempat di antara seluruh penduduk dunia atau 1,2 miliar hingga 1,5 miliar orang. Crystal melanjutkan bahwa data dari British Council memperkirakan, sekitar 275 juta orang menggunakan bahasa Inggris sebagai bahasa pertama dan 375 juta lainnya menggunakan sebagai bahasa kedua. Sekitar 750 juta lagi berbicara bahasa Inggris sebagai bahasa asing. Bahasa Inggris sekarang adalah bahasa yang paling banyak diajarkan sebagai bahasa kedua diseluruh dunia. Tidak kurang di 70 negara bahasa Inggris punya status bahasa resmi maupun khusus. Bahasa Inggris telah menjadi bahasa yang universal digunakan diseluruh dunia. Dengan menguasai bahasa Inggris, kita dapat berkomunikasi dan menjelajah dunia tanpa harus takut dengan perbedaan bahasa yang ada.

Untuk mengantisipasi hal tersebut, kita sebagai guru hendaknya mempunyai strategi mengantisipasi segala kemungkinan yang akan terjadi. Sejak dini kita pun perlu mengenalkan bahasa asing yang dalam hal ini, bahasa Inggris adalah bahasa yang resmi dijadikan sebagai bahasa internasional. Perkembangan ilmu pengetahuan dan teknologi sekarang ini, banyak disajikan dalam karya tulis ilmiah atau jurnal-jurnal ilmiah yang disajikan dalam bahasa Inggris.

Pembelajaran bahasa Inggris memiliki visi agar anak dapat memahami empat keterampilan bahasa, yaitu listening, speaking, reading, writing. Hal ini sesuai dengan pernyataan sebagai berikut.

Four language processes work together to enhance the development of each of the others: speaking, listening, reading, and writing. Listening and reading are the receptive processes (taking in information), and speaking and writing are the productive processes (giving out information).We might also include a fifth language process: thinking (language that takes place in your head ). Johnson (2008: 7)

Pendapan Johnson di atas memberikan sebuah informasi bahawa ke empat element keterampilan bahasa ini harus dikuasai oleh siswa, karena antara satu sama lain saling melengkapi perkembangan kemampuan berbahasa anak-anak. Untuk menyeimbangkan pembelajaran empat keterampilan berbahasa ini, guru harus benar-benar memahami kondisi psikologis anak agar mampu menciptakan suatu pembelajaran yang menarik dan bermakna. Bahasa Inggris secara umum diajarkan di Indonesia sebagai bahasa asing dan bukan sebagai bahasa kedua. Bahasa asing dalam pengertian bahwa bahasa yang diajarkan sebagai salah satu mata pelajaran di sekolah dengan tujuan berkomunikasi dasar serta menguasai empat keterampilan berbahasa yaitu listening, speaking, reading, writing. Metode pengajaran yang diterapkan sedikit berbeda antara bahasa Inggris sebagai bahasa asing dan sebagai bahasa ke dua. Apabila disebut sebagai bahasa asing, guru harus menggunakan banyak ilustrasi, gambar atau video. Sedangkan apabila disebut sebagai bahasa kedua, guru tidak harus menggunakan banyak ilustrasi, gambar ataupun video karena bagi yang menganggap sebagai bahasa ke dua sudah tidak asing lagi. Dengan 
demikian, pembelajaran bahasa Inggris di Indonesia harus di ajarkan dengan metode, teknik, dan strategi yang tepat.

Harun dan Bakar (2009) mengatakan bahwa Pembelajaran bahasa Inggris yang diterapkan di sekolah dasar hendaknya harus memperhatikan karakteristik siswa SD, ditinjau dari tingkat perkembangan intelektual dan fisiknya maupun tingkat perkembangan bahasanya. Kegiatan pembelajaran bahasa Inggris di sekolah dasar tidaklah mudah seperti yang dibayangkan. Selain kemampuan berbahasa Inggris yang baik yang harus dimiliki, guru juga harus memahami karakteristik, kemampuan berbahasa, serta perkembangan intelekual yang dimiliki oleh setiap siswa.

Menciptakan sebuah proses belajar yang menarik perhatian siswa tentu saja merupakan kewajiban guru yang memegang peranan penting ketika sudah berada di dalam kelas. Unsur kreativitas harus ditonjolkan agar siswa menjadi lebih tertarik akan pembelajaran bahasa Inggris. Sehingga tumbuh dalam benak siswa bahwa belajar bahasa Inggris adalah sebuah kegiatan yang menyenangkan dan menjadi sebuah kegiatan yang sangat dinantikan oleh siswa.

Dengan demikian, siswa akan menjadi lebih aktif, kreatif, analisis, dan lebih berpikir kritis. Salah satu hal yang harus diperhatikan oleh seorang guru dalam membelajarkan bahasa Inggris pada siswa adalah dengan menggunakan kegiatan yang melibatkan siswa secara aktif dalam mengembangkan keterampilan bahasanya. Salah satunya melalui kegiatan yang melibatkan kerja tangan (hands on practice). Hal tersebut didukung oleh salah satu teori dari Montessori yang yakin bahwa anak akan sangat baik belajar jika mereka belajar sambil melakukannya (learning by doing) dan sering melakukan pengulangan (Mooney, 2000: 29).

\section{Kajian Pustaka}

\section{Pengertian Reading Comprehension \\ Reading merupakan salah satu dari} empat ketrampilan berbahasa. Membaca adalah sebuah komponen dasar seseorang bisa memiliki pemahaman atau suatu pengetahuan yang lebih, karena dengan membaca, seseorang akan menjadi semakin kaya akan pengetahuannya. Membaca adalah merupakan suatu kegiatan yang dilakukan oleh seseorang untuk memperoleh informasi atau pengetahuan yang sebelumnya tidak diketahui oleh pembaca. Banyak cara yang dapat dilakukan manusia agar dapat membaca untuk memperkaya pengetahuannya. Membaca buku adalah suatu cara anak untuk dapat memperkaya vocabulary, dan yang paling penting adalah menciptakan suasana membaca yang nyaman agar kegiatan membaca dapat berjalan secara evektif (Scott dan Ytreberg :2003).

Sejalan dengan teori di atas Linse (2005: 69) medefinisikan reading sebagai " $a$ set of skills that involves making sense and deriving meaning from the printed word. In order to read, we must be able to decode (sound out) the printed word and also comprehend what we read."

Berdasarkan uraian di atas maka reading merupakan bagian dari keterampilan yang melibatkan perasaan dan pemerolehan makna dari kata yang dicetak. Di dalam membaca, siswa seyogyanya mahir dalam menerjemahkan kode dan membunyikan kata yang dicetak dan harus mengerti pula apa yang dibaca. Berdasarkan beberapa definisi di atas, dapat disimpulkan bahwa reading merupakan proses pemahaman atau penikmatan terhadap teks bacaan yang melibatkan proses berfikir, bernalar dan mengolah informasi, maupun mengamati tulisan secara visual dengan memanfaatkan kemampuan melihat (mata) untuk tujuan memperoleh informasi. 
Menurut Linse (2005:71) pada prinsipnya tujuan reading adalah sebagai berikut:

a. Reading for information, yaitu membaca yang dilakukan untuk mendapatkan informasi yang berguna untuk menambah wawasan dan ilmu pengetahuan

b. Reading for pleasure, yaitu membaca yang dilakukan untuk mencari kesenangan semata.

Dari pengertian di atas, Reading for information merupakan kegiatan reading yang dilakukan siswa untuk mendapatkan informasi dari buku yang telah mereka baca. Sebagai contoh ketika siswa membaca buku tentang dinaosaurus, mereka akan mendapat informasi tentang binatang prasejarah. Bahkan membaca untuk mendapatkan informasi juga dapat memberikan kesenangan untuk siswa. Reading for pleasure merupakan kegiatan membaca yang dilakukan siswa untuk mendapatkan suatu kesenangan. Contoh bacaan yang digunakan untuk reading jenis ini adalah story karena story dapat menyajikan kesenangan bagi siswa disemua usia.

Sejalan dengan pembahasan di atas, menurut Tarigan (2008: 9) tujuan utama dari membaca adalah mencari serta memperoleh informasi, mencakup isi, memahami makna bacaan. Sedangkan menurut Abidin (2010: 9), pada prinsipnya tujuan reading dapat digolongkan sebagai berikut:

1. Reading for knowledge, yakni dilakukan untuk menemukan berbagai pengetahuan atau informasi yang berguna dalam rangka mengembangakan wawasan dan ilmu pengetahuan pada diri seseorang.

2. Reading for product, yakni dilakukan untuk mendatangkan keuntungan dari segi finansial (usaha).

3. Reading for entertain, yakni membaca yang dilakukan untuk mendapatkan kenikmatan, kesegaran, dan kesenangan dari bahan-bahan bacaan yang dibacanya.
Berdasarkan uraian di atas, kegiatan reading memiliki banyak manfaat terutama bagi peserta didik dalam mencari dan memahami pengetahuan selama proses pembelajaran maupun di luar proses pembelajaran. Oleh karena itu, guru diharapkan dapat membantu peserta didik dalam mengembangkan kemampuan reading, dengan menggunakan metode, teknik, maupun strategi reading yang tepat dan sesuai dengan tujuan yang diperlukan.

Reading comprehension dapat diartikan sebagai serangkaian proses yang dilakukan pembaca untuk menemukan informasi dan memahami informasi yang terkandung dalam sebuah teks bacaan. Linse (2005: 71) menyatakan bahwa "reading comprehension refers to reading for meaning, understanding, and entertainment."

Hal ini berarti dalam membaca pemahaman terdapat serangkaian proses yang dilakukan pembaca untuk menemukan makna, memahami informasi yang terkandung dalam sebuah teks bacaan, dan hiburan. Dalam membaca pemahaman, para ahli sependapat bahwa skemata (pengetahuan awal yang dimiliki) pembaca menjadi penentu keberhasilan dalam membaca pemahaman. Peregoy dan Boyle (Linse, 2005: 69) menyatakan bahwa ada tiga hal yang membedakan siswa dalam membaca diantaranya: pengetahuan awal yang dimiliki siswa (the child's background knowledge), pengetahuan berbahasa siswa (the child's linguistic knowledge), dan strategi atau teknik membaca yang digunakan (the strategies or techniques the child uses). Sejalan dengan itu, Anderson, Hiebert, Scott, dan Wilkinson, 1985; Jenkins, Larson, dan Fleischer, 1983;O'Shea, Sindelar, dan O'Shea (Klinger, Vaughn, dan Boardman, 2007: 2) mengemukakan bahwa reading comprehension is the process of constructing meaning by coordinating a number of complex processes that include word reading, word and world knowledge, and 
fluency. Dengan demikian membaca pemahaman adalah proses yang bertujuan untuk membangun makna dengan mengkoordinasikan sejumlah proses yang kompleks yang meliputi membaca kata, kata dan pengetahuan.

Menurut Zimmerman (2009) Reading comprehension is essentially the ability to understand what has been read. Sejalan dengan itu, definisi lain menyebutkan bahwa Reading comprehension dapat diartikan juga sebagai serangkaian proses yang dilakukan pembaca untuk menemukan informasi dan memahami informasi yang terkandung dalam sebuah teks bacaan (Abidin, 2010:127).

Senada dengan definisi di atas, reading comprehension adalah jenis membaca yang bertujuan untuk memahami:

1) standar-standar atau norma-norma kesastraan (literary standards);

2) resensi kritis (critical review);

3) drama tulis (printed drama);

4) pola-pola fiksi (pettern of fiction).

(Tarigan, 2008: 58)

Dari beberapa pendapat dari para ahli di atas, peneliti menyimpulkan bahwa reading comprehension adalah serangkaian kegiatan atau proses yang dilakukan oleh pembaca untuk memperoleh pemahaman atas apa yang telah ia baca yang bertujuan untuk memperoleh informasi yang pembaca butuhkan. Selain itu, dapat diartikan kembali bahwa membaca pemahaman (reading for understanding) adalah serangkaian kegiatan membaca untuk mengetahui dan memahami apa yang belum diketahui dan belum dipahami.

\section{Metode Penelitian}

Penelitian ini menggunakan Penelitian Tindakan Kelas dimana penelitian yang dilakukan untuk memecahkan masalah, mengkaji langkah pemecahan masalah itu sendiri, dan atau memperbaiki proses pembelajaran secara berulang atau bersiklus (Abidin, 2011: 217).
Desain penelitian yang digunakan berbentuk siklus dengan beberapa tindakan penelitian dengan maksud untuk mencapai tujuan yang diharapkan. Desain penelitian yang dilaksanakan adalah model Elliot yang diadopsi dari Hopkins (Abidin, 2011:239)

Pelaksanaan penelitian ini berbentuk siklus dan setiap siklusnya terdiri dari tiga tindakan, dilaksanakan berulang dan berkelanjutan dengan langkah-langkah yang ditempuh adalah.

1. menetapkan kelas yang akan dijadikan subjek penelitian;

2. mengkaji kurikulum, materi ajar, buku paket, teori-teori belajar dan buku menunjang lainnya;

3. menyusun rancangan kegiatan yang sesuai dengan materi dan kondisi siswa;

4. merancang media belajar yang tepat;

5. membuat rencana pembelajaran;

6. mempersiapkan cara dan alat/instrumen pemantau/perekam data;

7. mengumpulkan dan menganalisis data;

8. membuat kesimpulan

Proses pelaksanaan PTK menurut Elliot ini terdiri dari menelaah, diagnosis, perencanaan, pelaksanaan, pemantauan, dan pengaruh menciptakan hubungan yang diperlukan antara evaluasi diri dari perkembangan professional. Model Elliot ini merupakan salah satu model yang lebih rinci dibandingkan dengan model lainnya karena di dalam setiap siklus dimungkinkan terdiri dari beberapa aksi yaitu antara 3-5 aksi (tindakan).

Bagan PTK menurut John Elliot dapat dilihat pada gambar 3.1 sebagai berikut. 


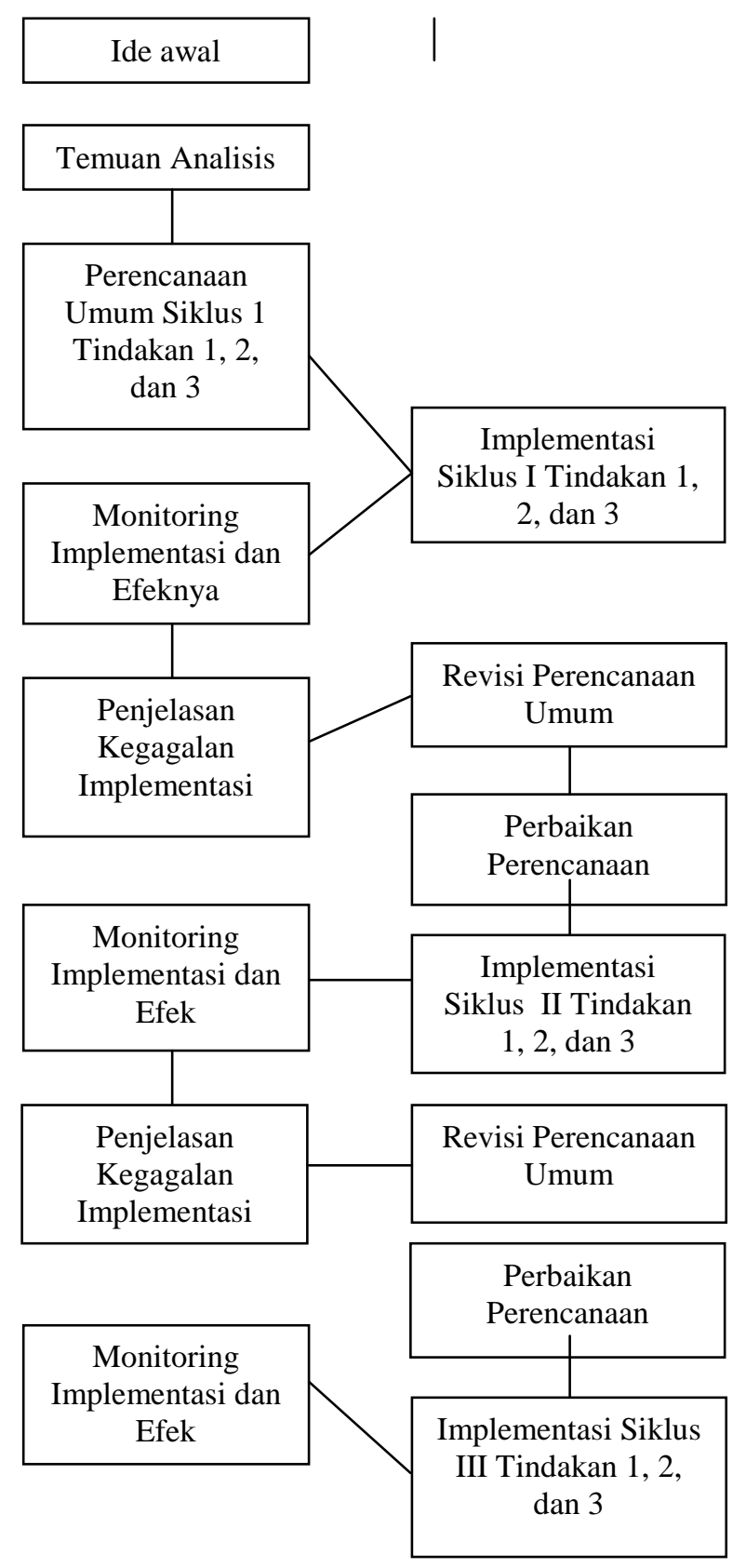

Gambar 1

Desain penelitian model Elliot Adapted from Hopkins, (Abidin, 2011:239).

Lokasi penelitian ini dilakukan di SDN Sindangkasih II Kecamatan Majalengka Kabupaten Majalengka. Subjek dalam penelitian ini adalah siswa kelas IV SD sebanyak 24 siswa yang terdiri dari 12 siswi perempuan dan 12 siswa laki-laki.

\section{Hasil Penelitian dan Pembahasan}

Berikut adalah hasil dari pembelajaran reading comprehension dengan penilaian dilakukan dengan memberikan tes dalam bentuk worksheet yang dikerjakan dengan cara berkelompok. Kemampuan reading comprehension siswa pada siklus pertama dapat dilihat dalam gambar sebagai berikut.

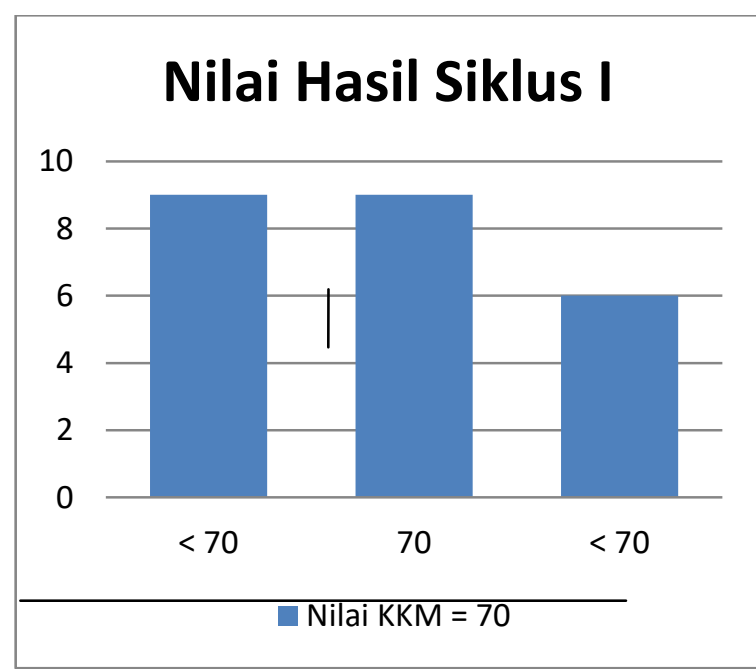

Gambar : 2

Grafik Penilaian Hasil Reading

Comprehension Siswa Siklus I

Dari data grafik di atas, dapat dilihat bahwa ada sembilan orang siswa $(37,5 \%)$ yang mendapatkan nilai dibawah KKM, sembilan orang siswa $(37,50 \%)$ mendapatkan nilai sesuai dengan KKM, dan enam orang siswa (25\%) mendapatkan nilai diatas KKM. Jika dilihat berdasarkan standar mastery learning terdapat enam siswa yang sudah dinyatakan tuntas belajar. Mastery learning adalah kriteria standar penilaian diatas dari nilai KKM yang ditetapkan oleh guru pamong untuk siswa. Sedangkan delapan belas siswa belum dinyatakan tuntas belajar karena belum berada di atas standar mastery learning yang berkisar pada nilai 75 .

Pada siklus kedua ini hasil pembelajaran reading comprehension siswa mengalami peningkatan dibandingkan dengan hasil pembelajaran pada siklus pertama. Hasil pembelajaran siklus kedua ini dapat dilhat pada gambar sebagai berikut. 


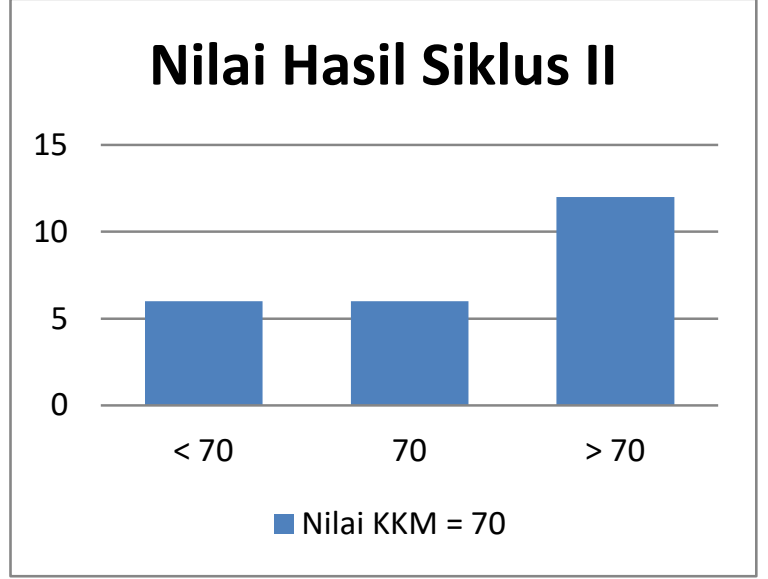

Gambar 3

Grafik Penilaian Hasil Reading

Comprehension Siswa Siklus II

Dari data grafik diatas, dapat dilihat bahwa ada 6 orang siswa (25\%) yang mendapatkan nilai dibawah nilai KKM yaitu 60,6 orang siswa $(25 \%)$ mendapatkan nilai sesuai dengan nilai standar KKM, dan ada 12 orang siswa $(50 \%)$ yang mendapat nilai diatas KKM. Jika dilihat berdasarkan standar mastery learning terdapat 18 siswa yang sudah dinyatakan tuntas belajar. Sedangkan 6 siswa belum dinyatakan tuntas belajar karena belum berada di atas standar mastery learning yang berkisar pada nilai 75 .

Pada siklus ketiga ini hasil pembelajaran reading comprehension siswa mengalami peningkatan dibandingkan dengan hasil pembelajaran pada siklus kedua. Hasil pembelajaran siklus kedua ini dapat dilhat pada gambar dibawah sebagai berikut.

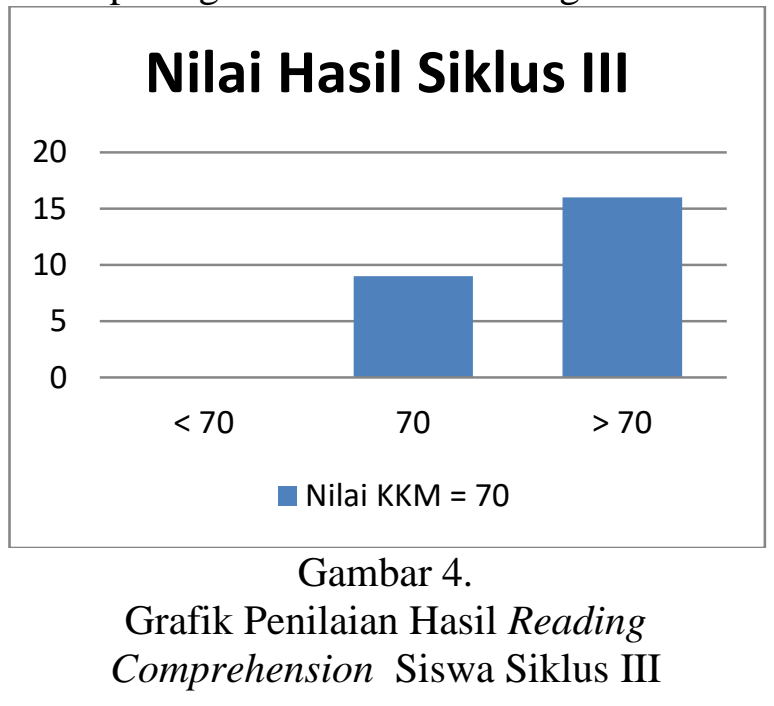

Dari data tabel diatas, dapat dilihat bahwa ada sembilan orang siswa $(37,5 \%)$ yang mendapatkan nilai sesuai dengan standar KKM yaitu 70, dan ada enam belas orang siswa $(66,66 \%)$ yang mendapat nilai diatas KKM. Jika dilihat berdasarkan standar mastery learning terdapat 16 siswa yang sudah dinyatakan tuntas belajar. Sedangkan sembilan siswa belum dinyatakan tuntas belajar karena belum berada di atas standar mastery learning yang berkisar pada nilai 75 .

Berdasarkan hasil penilaian pada siklus I, II dan III, maka dapat diuraikan peningkatan hasil belajar siswa dalam pembelajaran reading comprehension yang dapat dilihat pada gambar sebagai berikut.

\section{Rata-Rata Nilai Hasil}

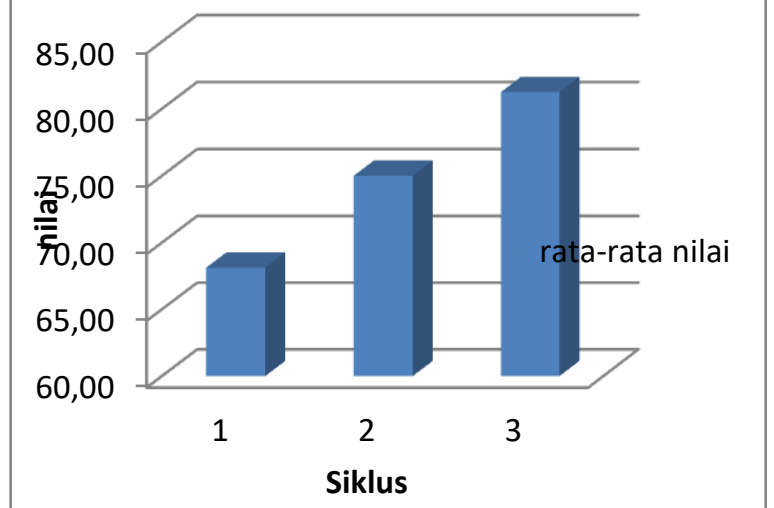

Gambar 5

. Diagram Penilaian Hasil Reading Comprehension Siswa

Berdasarkan diagram diatas, dapat dilihat bentuk peningkatan dari mulai siklus I, II dan III. Pada siklus I nilai rata-rata siswa dalam pembelajaran reading comprehension $(68,13$ $\%)$. Pada siklus dua, nilai rata-rata siswa adalah $(75,00 \%)$, dan sedangkan nilai ratarata pada siklus III adalah $(81,25 \%)$. Dari data diatas menunjukkan bahwa hasil nilai rata-rata siswa dalam pembelajaran reading comprehension terjadi peningkatan.

Pada siklus I nilai minimal siswa adalah sebesar 45, kemudian nilai maksimal adalah sebesar 85. Sehingga dari hasil keseluruhan nilai berdasarkan perhitungan 
rata-rata didapatkan hasil rata-rata siklus I sebesar $(68,13 \%)$. Pada siklus I prosentase yang sudah lulus berdasarkan nilai KKM adalah sebesar $(58,33 \%)$.

pada siklus II, nilai minimal yang didapatkan siswa adalah sebesar 60 . kemudian nilai maksimal siswa adalah sebesar 100. Sehingga dari hasil keseluruhan nilai berdasarkan perhitungan didapatkan hasil rata-rata siklus II sebesar $(75,00 \%)$. Kemudian pada siklus II prosentase yang sudah lulus berdasarkan nilai KKM adalah sebesar $(75 \%)$. Merujuk pada nilai rata-rata siklus I dan II, dapat dilihat adanya peningkatan rata-rata hasil pembelajaran siswa yaitu sebesar $(16,67 \%)$. Peningkatan terjadi karena pada pembelajaran di siklus dua terdapat perbaikan-perbaikan dan terjadi perubahana pada kemasan pembelajaran yang merujuk pada hasil revleksi pada siklus I. Sehingga temuan-temuan yang terdapat pada siklus I dapat diatasi dengan baik. Namun demikain, masih perlu diadakan perbaikan-perbaikan kembali untuk pelaksanaan pembelajaran pada siklus III agar terjadi peningkatan kembali pada hasil belajar reading comprehension.

pada siklus III, nilai minimal yang didapatkan siswa adalah sebesar 80 . kemudian nilai maksimal siswa adalah sebesar 100. Sehingga dari hasil keseluruhan nilai berdasarkan perhitungan rata-rata didapatkan hasil rata-rata siklus III sebesar $(75,00 \%)$. Pada siklus III prosentase yang sudah lulus berdasarkan nilai KKM adalah sebesar $(100 \%)$. Apabila melihat nilai ratarata pada siklus II dan III, terjadi peningkatan hasil pembelajaran reading comprehendion. Pada siklus dua nilai rata-rata belajar siswa adalah sebesar $(75,00 \%)$, sedangkan pada siklus III nilai rata-rata hasil belajar siswa adalah sebesar $(81,25 \%)$. Merujuk pada nilai rata-rata siklus II dan III, dapat dilihat adanya peningkatan rata-rata hasil pembelajaran siswa yaitu sebesar $(25,00 \%)$. Pada siklus III ini semua siswa mengalami peningkatan yang cukup signifikan.

\section{Simpulan dan Saran}

Adapun kesimpulan dari penelitian ini adalah sebagai berikut.

1. Cooperative learning make a match dapat membuat proses pembelajaran reading comprehension menjadi lebih aktif, kreatif, dan menyenangkan. Hal ini ditunjukkan dengan adanya peningkatan yang cukup signifikan pada proses pembelajaran di setiap siklus. Dari proses pembelajaran pada setiap siklus, siswa sudah menunjukkan kemajuan yang baik dalam kemampuan reading comprehension. Siswa telah mampu berpartisipasi secara aktif selama pembelajaran, siswa juga secara bertahap telah memahami instruksi yang disampaikan oleh peneliti. Selain itu, dengan menggunakan metode cooperative learning make a match proses pembelajaran reading comprehension bukan hanya melatih pemahaman dalam membaca saja, melainkan juga melatih motorik siswa dengan kegiatan make a match card games.

2. Cooperative learning make a match dapat meningkatkan hasil pembelajaran reading comprehension siswa. Hal ini terlihat dari hasil evaluasi atau tes siswa yang mengalami peningkatan cukup signifikan dalam setiap siklus. Pada siklus I ada lima belas orang siswa $(62,5 \%)$ dengan kemampuan reading comprehension baik. Adapun persentase siswa yang mencapai nilai KKM sebesar $62,5 \%$ dengan nilai rerata kelas sebesar 68,13. Kemampuan reading comprehension siswa mengalami peningkatan pada siklus II dengan adanya delapan belas orang siswa (75\%) dengan kemampuan reading comprehension baik. Adapun persentase siswa yang mencapai nilai KKM sebesar $75 \%$ dengan nilai rerata kelas menjadi sebesar 75. Kemampuan reading comprehension siswa mengalami peningkatan lagi pada 
siklus III dengan adanya dua puluh empat orang siswa (100\%) dengan kemampuan reading comprehension baik. Adapun persentase siswa yang mencapai nilai KKM sebesar $100 \%$ dengan nilai rerata kelas sebesar 81,25.

Setelah peneliti memaparkan hasil penelitian, maka peneliti menyampaikan beberapa saran. Adapun saran-saran yang ingin disampaikan peneliti adalah sebagai berikut.

1. Untuk penelitian selanjutnya, pelaksanaan pembelajaran reading comprehension dengan menggunakan instruksi tertentu seyogianya menggunakan bahasa yang mudah dipahami sesuai dengan tingkat kemampuan siswa. Oleh karena itu, guru sebaiknya menyesuaikan instruksi atau bahasa yang akan digunakan dengan tingkat kemampuan siswa;

2. Dalam penggunaan media pembelajaran alangkah baiknya lebih bervariatif lagi. Seperti menggunakan media sound system, infokus dan laptop untuk kegiatan pada saat menunjukan gambar dan musik pengiring pada saat melakukan permainan ketika kegiatan dilaksanakan di dalam kelas;

3. Penggunaan alokasi waktu pada saat permainan make a match agar lebih diperhatikan sesuai dengan kemampuan siswa. Jika alokasi waktu bisa dipangkas dengan tujuan meningkatkan pemahaman membaca siswa itu tidak menjadi masalah selama hasil yang diperoleh mengalami peningkatan yang cukup signifikan.

4. Untuk penelitian selanjutnya agar dalam merancang pembelajaran lebih variatif, motivatif, menarik, dan menyenangkan agar hasil yang diperoleh lebih maksimal.

\section{DAFTAR PUSTAKA}

Abidin, Y. (2010). Strategi membaca teori dan pembelajarannya. Bandung: RIZQI PRESS.

Abidin, Y. (2011). Penelitian Pendidikan dalam Gamitan Pendidikan Dasar dan Paud. Bandung: Rizqy Press.

Crystal, D. (2003). English as a Global Language. New York. Cambidge University Press.

DEPDIKNAS (2010). UU RI Nomor 20 Tahun 2003: Tentang SISDIKNAS \& PP RI Tahun 2010 Tentang Penyelenggaraan Pendidikan Serta Wajib Belajar. Bandung: Citra Umbara.

Harun dan Bakar, (2009). "Bahasa Inggris di Sekolah Dasar". Dalam Roni, Robandi MA. Dkk. (2009). Мепијu Pendidikan Dasar Bermutu. Bandung: RIZQI PRESS.

Johnson, A.P. (2008). Teaching reading and writing. New York: United Kingdom.

Klingner, J. K., Vaughn, S., dan Boardman, A. (2007). Teaching Reading Comprehension To Student With Leraning Difficulties. New York: The Guilford Press.

Linse, C. (2005). Practical English Language Teaching Young Learners. New York: McGraw Hill.

Mooney, C.G. (2000). Theories of Childhood: An Introduction to Dewey, Montessori, Erikson, Piaget, and Vygotsky. United States Of America : Redleaf Press.

Scott, W.A. dan Ytreberg, L.H. (2003) Teaching English to Children. New York: Longman. 
Tarigan, H. G. (2008). Membaca Sebagai

Suatu Keterampilan Berbahasa.

Bandung: Angkasa.

Zimmerman, J. (2009). Devinition of

Reading Comprehension [Online].

Tersedia:

http://www.ehow.co.uk/about_65934

85_definition-reading-compre-

hension. html [12 Desember 2010] 